\title{
シアリング接合部の木材繊維方向せん断性能に関する実験研究 EXPERIMENTAL STUDY ON SHEAR PERFORMANCE OF SHEAR-RING CONNECTOR
}

\author{
坂田弘安*1, 堀井健史 ${ }^{* 2}$, 竹内 徹*3, 中村博志*4, 松田和浩*5 \\ Hiroyasu SAKATA, Takeshi HORII, Toru TAKEUCHI, \\ Hiroshi NAKAMURA and Kazuhiro MATSUDA
}

\begin{abstract}
A composite member that thin steel plate was sandwiched between two cedar-glulam-timbers using shear-ring connectors and bolts was developed and equations for estimating the strength and buckling mode of the member were proposed.

In this paper, shear test results of shear-ring connector are reported because the shear stiffness of the shear-ring connector is important to use the equations for estimating the strength and buckling mode of the composite member. The shear stiffness, shear strength, destruction property of shear-ring connector is assessed by referring to method of the shear tests, thickness of cedar glulam timber, and so on. Additionally load transfer mechanism of shear-ring connector was comprehended.
\end{abstract}

Keywords: Shear-Ring Connector, Composite Member, Shear Performance of Connector, Japanese Cedar Glulam, Load Transfer Mechanism シアリング接合，ハイブリッド部材，接合部せん断性能，国産スギ集成材，力の伝達機構

1. 序

\section{1 背景と目的}

近年，意匠上の要求ならびに戦後植樹された国産材の有効利用と いう観点から，大型建築物に対して集成材等の木質材料を使用寸る 例が増えている。しかし， スギ材は他の樹種よりも剛性や耐力が低 いという点で構造材として不向きのため, スギの間伐材による大量 供給に対し，その需要は少ない。そこで我々は，スギ材を主に座屈 補剛材として用いた『シアリング接合を用いたスギ集成材と鋼板に よるハイブリッド部材(図 1)』を開発した。このハイブリッド部材は, ドーム等の屋根部材として用いられる張弦梁の圧縮材を想定して開 発した。このハイブリッド部材には軸圧縮および曲げが生じるため, 筆者らは軸圧縮と曲げの中で最も厳しい条件である等曲げを受ける ときの座屈耐力の評価式を提案している ${ }^{1)}$ 。その評価式は軸耐力お よび等曲げ耐力のどちらにおいても鋼板とスギ集成材の繊維方向の 一体性の度合いを考慮した式となっており，鋼板とスギ集成材を接 合しているシアリング接合(図 2)の繊維方向すべり剛性が重要な役 割を担っている。

一方，リング形式の接合金物のせん断性能に関する研究例に目を 向けると, 福田 ${ }^{2)}$, 長沼 ${ }^{3)}$, 原田ら ${ }^{4)}$ によりジベルの許容せん断耐 力に関する検討が行われている。比較的新しい研究報告例としては, 神谷ら ${ }^{5)}$ や大橋ら ${ }^{6}$ が $102 \mathrm{~mm}$ 径のジベルのせん断実験により許容 せん断耐力の検討を，今井ら ${ }^{7), 8}$ は圧入ジベルの押し抜き実験によ
り許容せん断耐力やすべり剛性の検討を行っている。また, 海外で もジベルは有効な木材の接合手段として広く用いられており, 様々 なせん断実験により許容せん断耐力やジベルが複数個配列されたと きの耐力に関して検討が行われている ${ }^{9), 10) な と ゙ 。 ~}$

リング形式の接合金物は我々が提案したようなハイブリッド部材 以外に, 住宅等の小規模建築にも適用できるなど様々な用途がある。

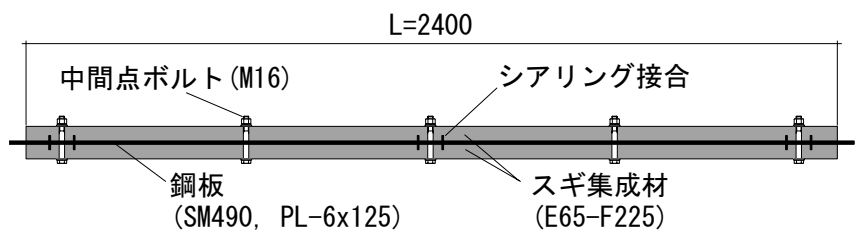

図 1 提案したハイブリッド部材 ${ }^{1)}$

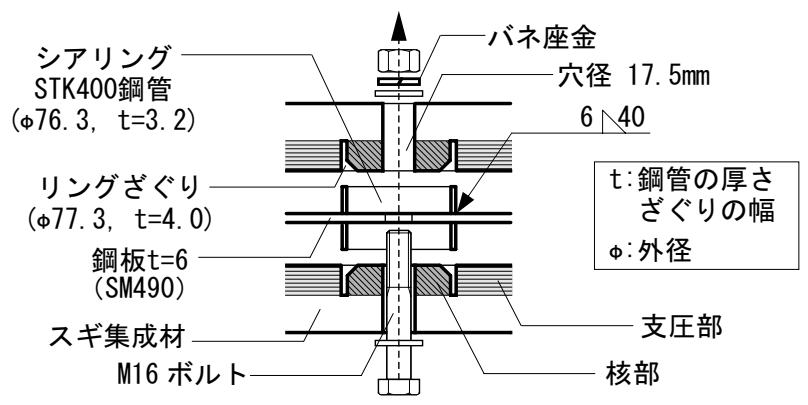

図 2 スギ集成材と鋼板の接合部（単位：mm）
*1 東京工業大学建築物理研究センター 准教授. 工博

*2 大成建設株) 修士 (工学)

*3 東京工業大学建築学科 准教授・博士 (工学)

*4 新日鉄エンジニアリング(侏) 博士 (工学)

*5 東京工業大学 大学院生・修士 (工学)
Assoc. Prof., Struct. Eng. Res. Center, Tokyo Institute of Technology, Dr. Eng. Taisei Corporation, M. Eng.

Assoc. Prof., Dept. of Architecture and Build. Engng., Tokyo Institute of Technology, Dr. Eng.

Nippon Steel Engineering Co., Ltd., Dr. Eng.

Graduate Student, Tokyo Institute of Technology, M. Eng. 
木材と鋼板との有効な接合方式の一つであるシアリング接合のせん 断性能に関して詳細な検討を行うことは, 様々な建物の設計自由度

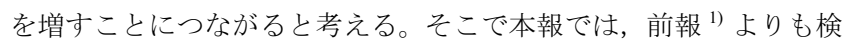
討範囲を拡大したシアリング接合部のせん断実験を行い，シアリン グ接合の寸べり剛性・耐力・破壊性状・力の伝達機構に関して基礎 的データを得ることを目的とする。

\section{2 シアリング接合}

ハイブリッド部材を開発するにあたり，集成材と鋼板の接合に対 して以下 $3 つ の$ 性能を課した。

(1)ハイブリッド部材を構成する上で十分なすべり剛性およびせん 断耐力を有していること。

(2)接着剤を用いないドライ工法であること。

(3)解体を容易に行うことができ, かつ解体後の部材を再利用でき ること。

これらの条件を満たすものとしてシアリング接合を選定している。 シアリング接合の構成は以下に示寸とおりである。図 2 に示すよ うに, 厚さ $6 \mathrm{~mm}$ の鋼板の表裏面に STK 400 鋼管(外径 76.3 , 管厚 3.2 , 高さ $18 \mathrm{~mm}$, 以下シアリングと呼ぶ)をすみ肉溶接し, スギ集成材に リングざぐり (外径 77.3 , 幅 4.0, 深さ $20 \mathrm{~mm}$ )を設ける。その後, リ ングざぐりにシアリングを嵌め込み，バネ座金が閉じるまで M16 の六角中ボルトで締め付け，スギ集成材と鋼板を一体化させたもの である。ここで, 図 2 に示すようにリングざぐりの中央部を核部, リングざぐりの外側を支圧部と呼ぶことにする。

\section{2. 実験概要}

表 1 に試験体に用いた材料の力学的特性, 表 2 に試験体一覧, 図 3 に試験体を示す。シアリング接合部要素実験は大きく 2 シリーズに 分けられる。シリーズ 1 は境界条件・スギ集成材の形状・載荷方向・ 樹種をパラメータとしたもので, それらがシアリング接合の荷重一 すべり関係に与える影響を調べた。シリーズ 2 はシアリング接合の 力の伝達機構を調べるために行った。両シリーズとも全てラミナ積 層面に対して平行に載荷し, 載荷速度は $0.5 \mathrm{~mm} / \mathrm{min}$ 以下とした。

\section{1 試験体}

2. 1.1 シリーズ 1

図 3 に示寸ようにシリーズ 1 の試験体パラメータは, (1)境界条件, (2)支圧部間の長さ $h$, (3)スギ集成材の材厚 $t$, (4)載荷方向, (5)樹種で, パラメータ毎に 3 体ずつの実験を行った。

(1)境界条件

我々が提案したハイブリッド部材では, シアリング接合はシアリ ング同士で押し合うように用いられる。そのため載荷方法は図 4 に 示すように上下の鋼板を分離させ, シアリング同士で押し合う R タ イプを用いた。さらに,より単純な試験体で要素実験を行えるかを 検討するために, 図 3 (b) に示すように, R タイプの支圧部間の長さ $h$ を半分, もしくは支圧部以下の長さ $h$ を揃え, スギ集成材の底面で 反力を取った B タイプを用いた。ここで支圧部間の長さ $h$ は, 図 3 に示すようにリングざぐりの外縁間内のり距離とした。

(2)支圧部間の長さ $h$ と(3)スギ集成材の材厚 $t$

支圧部間の長さ $h$ は, R タイプは $h=200,648 \mathrm{~mm}$ の 2 種類, B タイ プは Rタイプの $h=200 \mathrm{~mm}$ に対応しており $h_{B}=100,200 \mathrm{~mm} の 2$ 種類 とした。スギ集成材の材厚 $t$ は $t=30,45,60 \mathrm{~mm}$ の 3 種類とした。
表 1 材料の力学的特性

\begin{tabular}{c|c|c|c}
\hline $\begin{array}{c}\text { 鋼板 } \\
\text { SM490 }\end{array}$ & $\begin{array}{c}\text { 伸び } \\
22[\%]\end{array}$ & $\begin{array}{c}\text { 降伏強度 } \\
433\left[\mathrm{~N} / \mathrm{mm}^{2}\right]\end{array}$ & $\begin{array}{c}\text { 引張強度 } \\
551\left[\mathrm{~N} / \mathrm{mm}^{2}\right]\end{array}$ \\
\hline \hline $\begin{array}{c}\text { 集成材 } \\
\text { スギ/ベイマッ }\end{array}$ & $\begin{array}{c}\text { 曲げ弾性係数 } \\
{\left[\mathrm{kN} / \mathrm{mm}^{2}\right]}\end{array}$ & $\begin{array}{c}\text { 曲げ強さ } \\
{\left[\mathrm{N} / \mathrm{mm}^{2}\right]}\end{array}$ & $\begin{array}{c}\text { 含水率 }[\%] \\
\text { 気乾比重 }\end{array}$ \\
\hline スギx-x方向 & 7.1 & 48.0 & 14.0 \\
\cline { 1 - 2 } スギy-y方向 & 6.4 & 48.9 & 0.38 \\
\hline ベイマツx-x方向 & 14.0 & 70.4 & 19.8 \\
\cline { 1 - 2 } ベイマツy-y方向 & 13.4 & 65.1 & 0.52 \\
\hline
\end{tabular}

$x-x$ : ラミナ積層面に直交に載荷 $y-y$ : ラミナ積層面に平行に載荷

表 2 試験体一覧

\begin{tabular}{|c|c|c|c|c|c|}
\hline 試験体名 & $\begin{array}{l}\text { シリ } \\
\text { ーズ }\end{array}$ & $\begin{array}{l}\text { 反カを } \\
\text { 取る物 }\end{array}$ & $\begin{array}{c}\text { 支圧部間 } \\
\text { の長さ }\end{array}$ & 集成材断面 & 樹種 \\
\hline Rh200t45 & \multirow{8}{*}{1} & \multirow{4}{*}{$\begin{array}{l}\text { シア } \\
\text { リング }\end{array}$} & \multirow{3}{*}{200} & $2 \square-45 * 150$ & \multirow{7}{*}{ スギ } \\
\hline Rh200t30 & & & & $2 \square-30 * 150$ & \\
\hline Rh200t60 & & & & $2 \square-60 * 150$ & \\
\hline Rh648t45 & & & 648 & \multirow{8}{*}{$2 \square-45 * 150$} & \\
\hline Bh100t45 & & \multirow{2}{*}{ 木ロ } & 100 & & \\
\hline Bh200t45 & & & \multirow{5}{*}{200} & & \\
\hline Rh200t45-te & & \multirow{4}{*}{$\begin{array}{c}\text { シア } \\
\text { リング }\end{array}$} & & & \\
\hline Rh200t45-df & & & & & ベイマツ \\
\hline Rh200t45-bo & \multirow{3}{*}{2} & & & & \multirow{3}{*}{ スギ } \\
\hline Rh200t45-nc & & & & & \\
\hline Bh100t45-nb & & 木口 & 100 & & \\
\hline
\end{tabular}

te:引張載荷 $d f$ :ベイマッ $n b$ :支圧部無 $n c$ :核部無 bo:ボルト接合

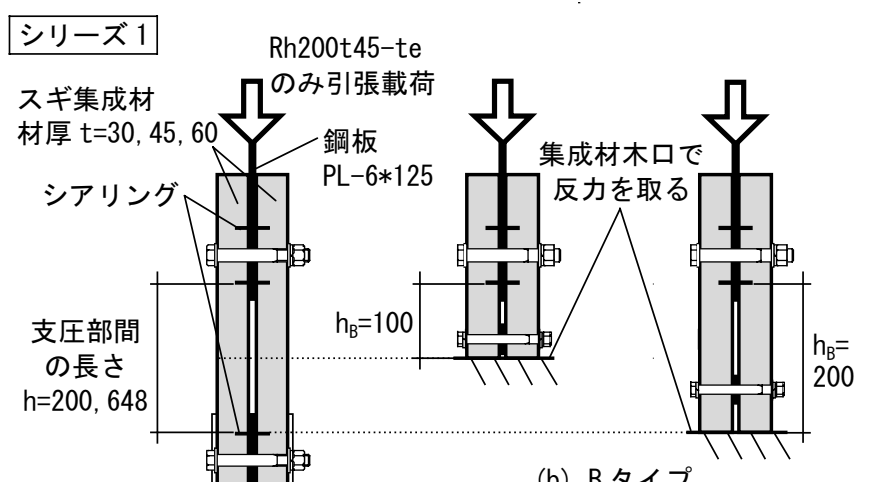

(b) Bタイプ

(Bh100t45, Bh200t45)

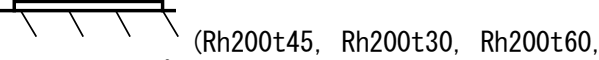

(a) Rタイプ Rh648t45. Rh200t45-te, Rh200t45-df)

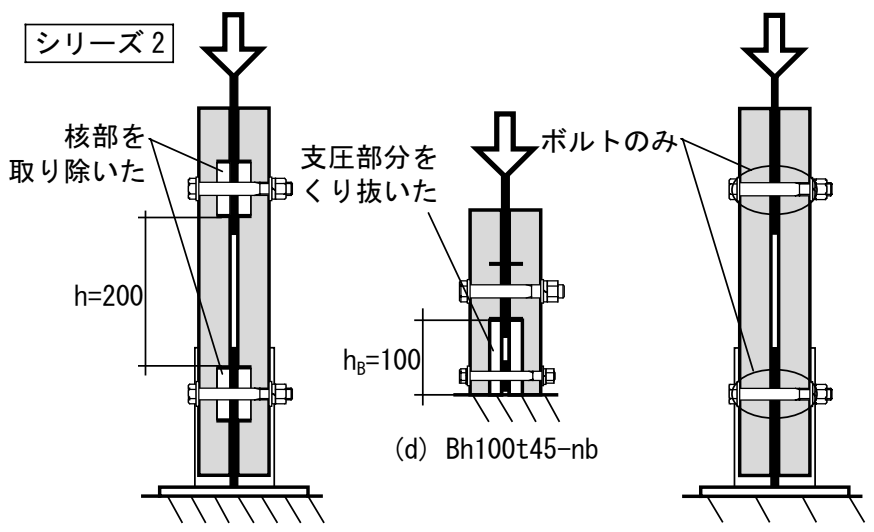

(c) Rh200t45-nc

図 3 試験体 (e) Rh200t45-bo

(単位 : mm) 
(4)載荷方向

単調圧縮載荷を基本としたが, Rh200t45-te の久単調引張載荷を 行った。

(5)樹種

Rh200t45 では，強度等級 E65-F225 のスギ集成材と E135-F375 のベ イマツ集成材 (Rh200t45-df)の 2 種類を用意し, その他の試験体につ いては全て強度等級 E65-F225 のスギ集成材を用いた。

2. 2 シリーズ 2

シリーズ 2 の試験体パラメータは, (1)核部の有無, (2)ング間の 支圧部の有無, (3)シアリングの有無である。パラメータ毎に 3 体ず つ実験を行った。

Rh200t45 試験体について, 核部・リング間の支圧部・ボルトの支 圧部それぞれが負担する力を把握するために，核部をくり抜いた Rh200t45-nc 試験体(図 3(c))，リング間の支圧部分をくり抜いた Bh100t45-nb 試験体(図 3(d)) , シアリングのないボルト接合のみの Rh200t45-bo 試験体(図 3(e))を製作した。全てに単調圧縮載荷した。

\section{1 . 2 計測}

図 5 に示寸ようにシアリング間における鋼板の変位 $\Delta_{1}$ とスギ集 成材の変位 $\Delta_{2}$ を計測し, シアリング片面 1 個あたりのすべり $\Delta$ を $\mathrm{R}$ タイプについては式(1)で, B タイプについては式(2)で算出し, 変 形能力のある試験体でも $\Delta=10 \mathrm{~mm}$ を越えたら載荷を終了した。

$$
\begin{aligned}
& \Delta=\frac{\Delta_{1}-\Delta_{2}}{2} \\
& \Delta=\Delta_{1}-\Delta_{2}
\end{aligned}
$$

\section{3. シリーズ 1 の実験結果の比較と考察}

図 6 にシアリング片面 1 個あたりの荷重一寸心゙り関係（以下，荷 重一すべり関係）を，表 3 に全試験体における最大耐力と初期す心゙ り剛性を示す。初期すべり剛性は各試験体ごとに最大耐力の 20〜 $50 \%$ のデータ群から最小二乗法によって得られる直線の傾きと定義 した。ここでは, Rh200t45 を標準試験体と位置づけて, 他の試験体 との考察を行う。

\section{1 境界条件}

シアリング同士で押し合った Rh200t45 試験体とスギ集成材底面 で反力を取った Bh100t45 試験体, Bh200t45 試験体を比較する[図 6(b) の(1)と(5)と(6)]。直線域から求まる初期すべり剛性 $K_{1}$ は, 表 3 に示 すように Rh200t45 試験体の $37.1 \mathrm{kN} / \mathrm{mm}$ に対して，スギ集成材の底 面で反力をとった Bh100t45 試験体と Bh200t45 試験体ではそれぞれ $48.1 \mathrm{kN} / \mathrm{mm}, 47.4 \mathrm{kN} / \mathrm{mm}$ と，B タイプの方が高い初期すべり剛性を 示した。また, 最大耐力も $\mathrm{B}$ タイプの方が高い。この違いは, B タ イプはスギ集成材底面で面外変形を拘束したためと考えられる。こ のことは, 剛性低下後の挙動の違いにも現れており, B タイプはボ ルトのロープ効果により緩やかに耐力が上昇し続けたのに対して, Rh200t45 試験体はシアリング間の亀裂の進行と共に耐力が徐々に 低下した。Rh200t45 試験体は上下のシアリングがスギ集成材を材軸 方向に引き裂いたことにより剛性・耐力が低下したが， B タイプで はスギ集成材の底面で摩擦が生じたため，スギ集成材の材軸方向の 亀裂が Rh200t45 試験体に比べて進行が遅く, 大きなすべりまでシア リングのスギ集成材に対する支圧で力を伝達できたからである。

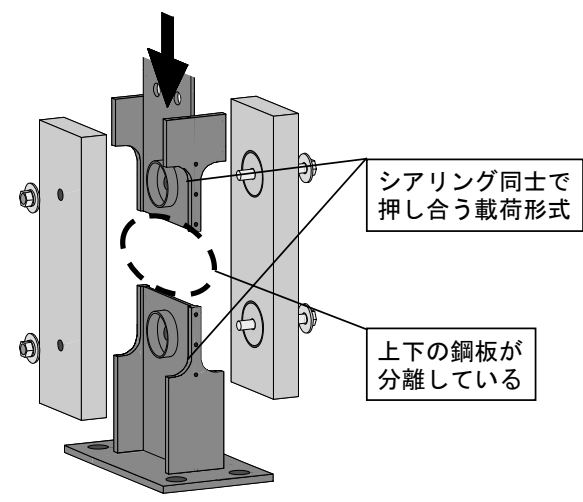

図 4 試験体の構成 (Rタイプの場合)

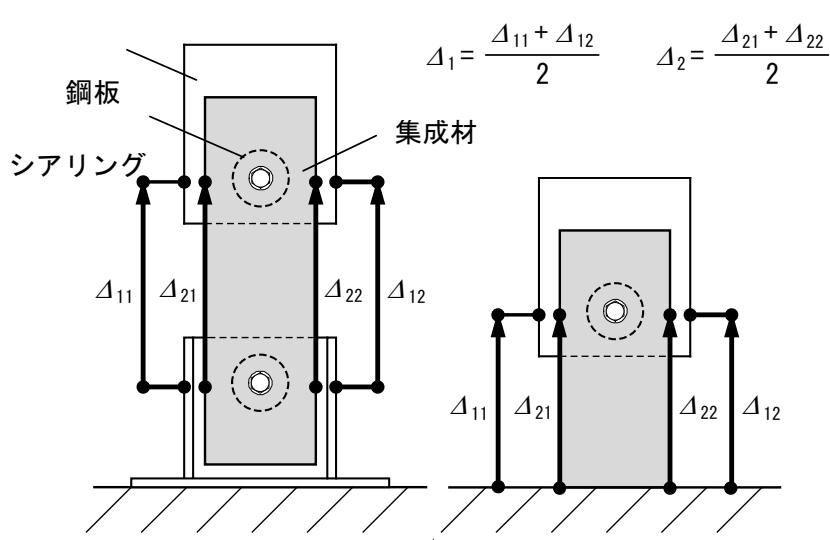

(a) $\mathrm{R}$ タプ

(b) Bタイプ

図 5 変形の計測

表 3 最大耐力と初期すべり剛性

\begin{tabular}{l|c|c|c|c|c|c|c|c}
\hline & \multicolumn{3}{|c|}{ 最大耐力 $\mathrm{P}_{\max }[\mathrm{kN}]$} & \multicolumn{3}{c}{ 初期すべり剛性 $\mathrm{K}_{1}[\mathrm{kN} / \mathrm{mm}]$} \\
\hline \hline \multicolumn{1}{c|}{ 試験体 } & 1 & 2 & 3 & 平均值 & 1 & 2 & 3 & 平均値 \\
\hline Rh200t45 & 42.4 & 46.6 & 44.8 & 44.6 & 30.9 & 41.7 & 38.6 & 37.1 \\
\hline Rh200t30 & 41.8 & 26.8 & 36.9 & 35.2 & 38.3 & 15.7 & 32.7 & 28.9 \\
\hline Rh200t60 & 45.4 & 47.0 & 50.3 & 47.6 & 26.3 & 29.8 & 24.6 & 26.9 \\
\hline Rh648t45 & 52.2 & 54.9 & 49.5 & 52.2 & 38.6 & 48.0 & 38.1 & 41.6 \\
\hline Bh100t45 & 62.4 & 62.1 & 59.4 & 61.3 & 57.7 & 38.6 & 48.0 & 48.1 \\
\hline Bh200t45 & 58.7 & 49.6 & 53.2 & 53.8 & 46.4 & 52.4 & 43.4 & 47.4 \\
\hline Rh200t45-te & 19.4 & 16.1 & 16.0 & 17.2 & 21.2 & 19.8 & 18.5 & 19.8 \\
\hline Rh200t45-df & 54.7 & 77.1 & 73.7 & 68.5 & 41.7 & 38.1 & 33.4 & 37.7 \\
\hline Rh200t45-bo & 20.9 & 22.6 & 21.5 & 21.7 & 9.7 & 7.9 & 11.1 & 9.6 \\
\hline Rh200t45-nc & 35.4 & 44.1 & 37.5 & 39.0 & 29.4 & 24.9 & 18.3 & 24.2 \\
\hline Bh100t45-nb & 14.2 & 15.1 & 14.2 & 14.5 & 14.0 & 9.5 & 8.3 & 10.6 \\
\hline
\end{tabular}

以上のことから，シアリング接合をシアリング同士で押し合うよ うに用いることを想定する場合，B タイプのようにスギ集成材底面 で反力を取った試験体で要素実験を行うのは適切でない。

Rh200t45 試験体および B タイプ共に, シアリングのスギ集成材に 対する支圧部分のめり込み，ボルトのスギ集成材ボルト孔に対する 支圧部分めり込み，核部のせん断ずれ(写真 1 (a) (c))が見られた。 支圧部の繊維の潰れた深さは Rh200t45 試験体で $3 \mathrm{~mm}$ 程度，B タイ プでは $10 \mathrm{~mm}$ 程度と $\mathrm{B}$ タイプの方が大きい。B タイプにおいてはボ ルトの曲げ変形(写真 1 (d))が見られたが，Rh200t45 試験体において はボルトの曲げ変形は見られなかった。材軸方向の亀裂は, Rh200t45 試験体においては複数本見られたが，B タイプにおいては 1 ないし は 0 本であった(写真 1 (e),(f))。 


\section{2 支圧部間の長さ}

支圧部間の長さ $h$ で初期すべり剛性を比較すると[図 6(b)の(1) と (4)及び(5)と(6)], Rh200t45 試験体と Rh648t45 試験体とでは, ほぼ同 じであった。同様に，Bh100t45 試験体と Bh200t45 試験体を比較し ても，初期すべり剛性に顕著な違いは見られなかった。これは剛性 がリング支圧部の局所的な変形に支配されているためと考えられる。

最大耐力を比較すると， $\mathrm{R}$ タイプでは支圧部以下の長さの長い Rh648t45 試験体の方が Rh200t45 試験体よりも高く，B タイプでは 支圧部以下の長さの短い Bh100t45 試験体の方が Bh200t45 試験体よ りも高い。これは，B タイプにおいては，支圧部以下の長さが短い 方がスギ集成材底面における摩擦による変形の拘束が働くためであ ると考えられる。材軸方向の亀裂によってすべり剛性が低下した $\mathrm{R}$ タイプにおいては，支圧部以下の長さの長い方が割裂面の面積が大 きくなるため，最大耐力も大きくなると考えられる。

\section{3 スギ集成材厚 $\mathrm{t}$}

Rh200t30 試験体，Rh200t45 試験体，Rh200t60 試験体でスギ集成 材厚 $t$ に関して比較すると[図 6(c)の(1)と(2)と(3)]，直線域における 初期すべり剛性の差は小さい。Rh200t30 試験体の最大耐力は Rh200t45 試験体の $75 \%$ 程度で, 最大耐力到達後は粘ることなく亀裂 の進行と共に耐力が低下した。従って，スギ集成材厚 $t$ による初期
すべり剛性の違いは見られないが，材厚が薄いと耐力が低く脆性的 な挙動をすることに注意する必要がある。Rh200t60 試験体の最大耐 力は Rh200t45 試験体より若干高く, 変形能力は明らかに大きい。こ のことから，45mm 以上に材厚が増えると勒性は高くなるが，最大 耐力に対寸る影響は少ないといえる。

\section{4 載荷方向}

単調圧縮載荷を行った Rh200t45 試験体と単調引張載荷を行った Rh200t45-te 試験体を比較すると[図 6(d)の(1)と(7)]，引張荷重を受 ける場合の初期す心゙り剛性は圧縮荷重を受ける場合の $1 / 2$ 程度, 耐 力は $1 / 3$ 程度であった。また，引張荷重を受ける場合は，最大耐力 到達時にシアリングのスギ集成材に対する支圧部分が抜けたため (写真 $1(\mathrm{~g}))$ ，粘ることなく耐力が急激に低下した。このことから, 引張荷重を受け，端空きが短い箇所においては初期すべり剛性・耐 力ともに注意を寸る必要があることがわかる。

\section{5 材種}

スギ集成材を用いた Rh200t45 試験体と,ベイマツ集成材を用いた Rh200t45-df 試験体を比較すると[図 6(d)の(1)と(8)]，初期すべり剛性 に関してはほぼ同じであった。而力は，集成材の曲げ強さに比例し た值となった。最終的には，集成材に関しては両者とも同じような 破壊性状が見られたが，ベイマツ集成材を用いた場合は，耐力が高

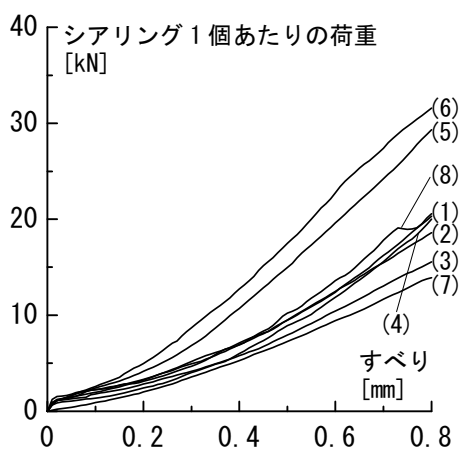

(a) 初期の挙動

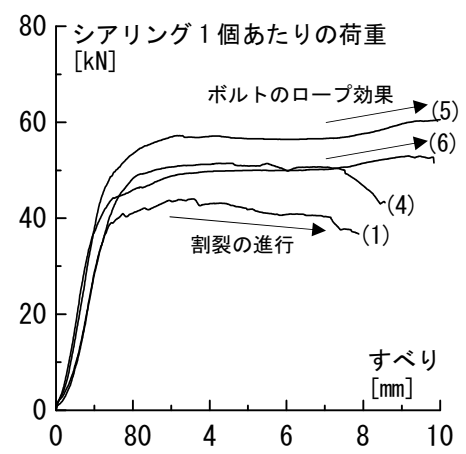

(b) 境界条件と支圧部以下の長さ

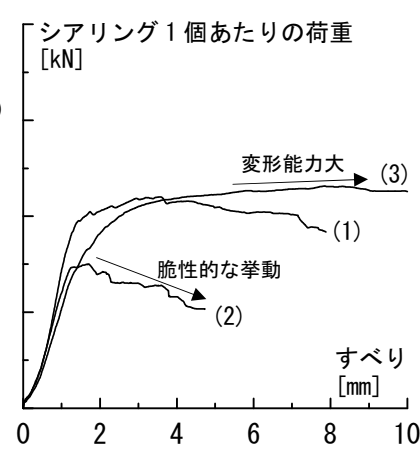

(c) 集成材厚

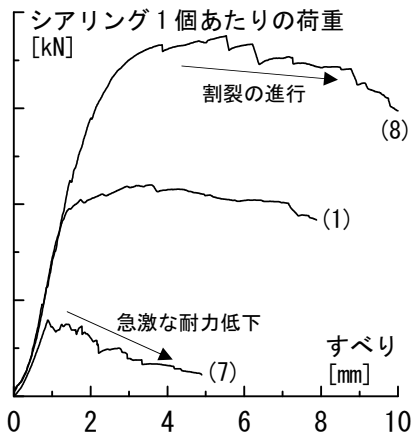

（d）載荷方向と材種

(1) :Rh200t45，(2):Rh200t30，(3):Rh200t60，(4):Rh648t45，(5):Bh100t45，(6):Bh200t45， (7):Rh200t45-te， (8):Rh200t45-df 図 6 シリーズ 1 のシアリング 1 個あたりの荷重一寸べり関係

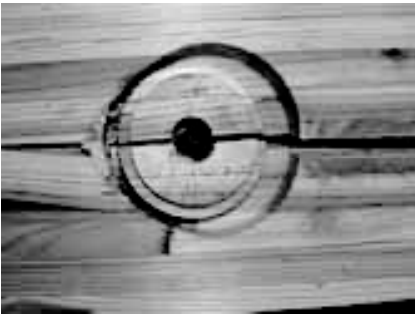

(a) Rh200t45

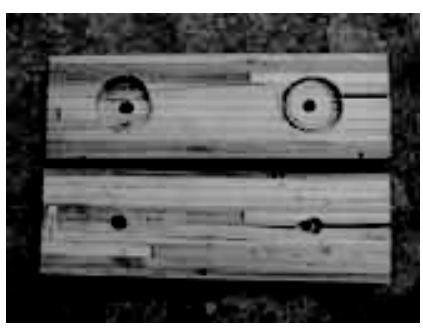

(e) Rh200t45

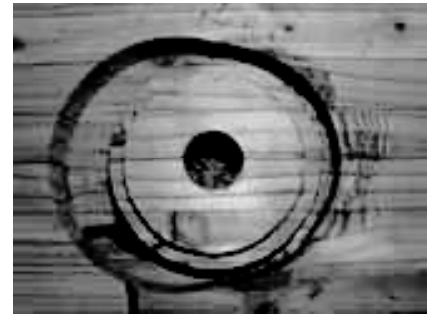

(b) Bh200t45

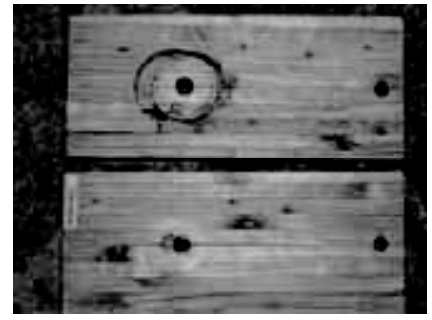

(f) Bh200t45

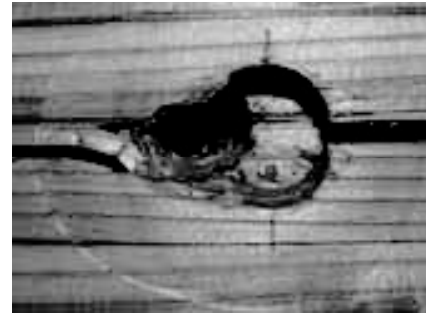

(c) Rh200t45

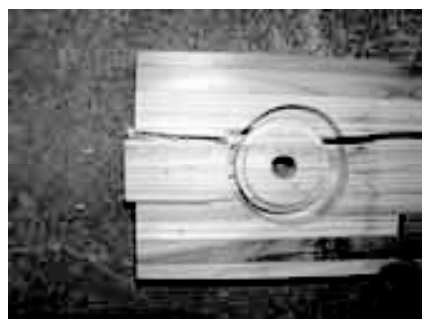

(g) Rh200t45-te

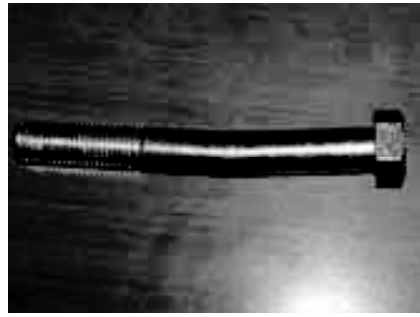

(d) Bh100t45

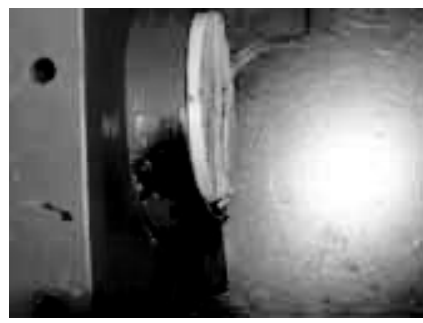

(h) Rh200t45-ns

写真 1 破壊性状 
かったため，シアリングに残留変形が見られた(写真 1 (h))。

\section{4. シアリング接合部のカの伝達機構}

Rh200t45 試験体, Rh200t45-nc 試験体, Bh100t45-nb 試験体, Rh200t45-bo 試験体の荷重一寸べり関係を図 7 に示す。シアリング 接合は, 図 8 に示すように, (1)ボルトのスギ集成材ボルト孔に対す る支圧，(2)リングざぐり中央の核部のせん断，(3)シアリング外側の スギ集成材に対する支圧によって力を伝達すると考えられる。ここ では，シアリング接合の力の伝達機構に対して上記(1)〜(3)を用いて 考察し，さらにそれぞれが負担する力の割合を調べる。すなわち， まずシアリング接合におけるボルトの支圧のみ・核部のせん断の み・シアリングの支圧のみの荷重一寸べり関係を抽出し，その合計 とRh200t45 試験体の荷重一すべり関係を比較する。

\section{1 1)ボルト部の荷重一すべり関係の抽出}

ボルトのスギ集成材ボルト孔に対する支圧は，シアリング接合に おける場合と，Rh200t45-bo 試験体の場合で支圧条件が異なる。す なわち，図 9 に示寸ように，Rh200t45-bo 試験体ではスギ集成材の 全幅で支圧を負担するが，シアリング接合の場合は，図 8(1)のよう に核部の外側の部分のみが支圧を負担すると考える。

スギ集成材を弾性床, ボルトを弾性床上の梁として図 10 のように モデル化し，梁要素の中央に鉛直方向に集中荷重をかけた。 $\mathrm{R}$ タイ プの試験体のスギ集成材の高さはボルト内のり間隔 $260 \mathrm{~mm} の$ 半分 として $130 \mathrm{~mm}$ に設定した。ここで梁(ボルト)の半分を, 図 11 のよ うに集成材から突き出しのある有限長のボルトと考え，回転拘束さ れたボルト中央部ボルトの半分の荷重が作用寸るものと考えれば,

Y.L. Chang の式のを参考に,

(集成材からの突き出し部分) $E I \frac{d^{4} y_{Z}}{d z^{2}}=0 \quad(0 \leq z \leq h)$

(集成材部分) $\quad E I \frac{d^{4} y_{X}}{d x^{2}}+B k_{h}=0 \quad(0 \leq x \leq L)$

ただし，EI: ボルトの曲げ岡性， $B k_{h}$ : 集成材反力係数(一定)

となる。シアリング接合では $h=21 \mathrm{~mm}, L=27 \mathrm{~mm}$ ，ボルト接合では $h=3 \mathrm{~mm}, L=45 \mathrm{~mm}$ として式(3),(4)を解くことによりたわみ曲線式 を求めることができる。集成材の奥行きはボルトの直径と同じ $16 \mathrm{~mm}$ として計算を行った結果，同一荷重時における中央たわみの 比はボルト接合: シアリング接合で $1: 0.54$ となった。したがって, シアリング接合におけるボルトの荷重一すべり関係は，要素実験で 行ったボルト接合の荷重を 0.54 倍した值と寸る。

さらに, Rh200t45-bo 試験体においてはボルトと鋼板のボルト孔 およびスギ集成材のボルト孔のクリアランスの影響が出ないように, ボルトとボルト孔を接触させた状態で試験体を組み上げたが，シア リング接合の試験体に関してはそのような処置は施せない。従って, 載荷前のボルト位置は平均でボルト孔の中央にあると判断する。す なわち，シアリング接合におけるボルトの支圧力は，載荷開始時に クリアランス分だけす心゙ってから発揮し始めることを考慮し，荷重 一すべり関倸においてすべりを正側に $1.25 \mathrm{~mm}$ オフセットした。以 上の作業により抽出されたボルト部の荷重一すべり関係を図 12(a) に示す。

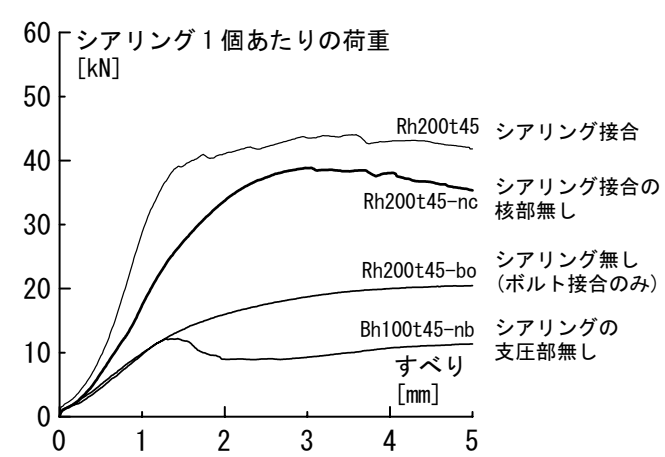

図 7 シリーズ 2 の荷重一すべり関係

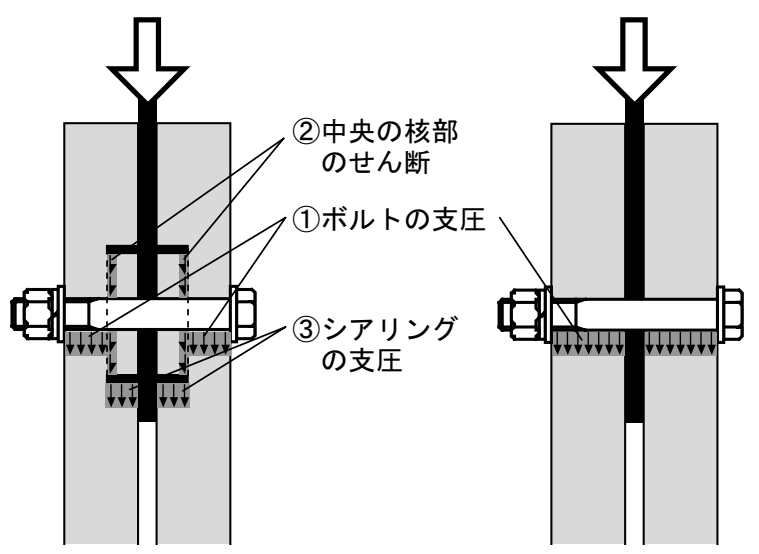

図 8 シアリング接合の力の流れ

図 9 ボルト接合の力の流れ

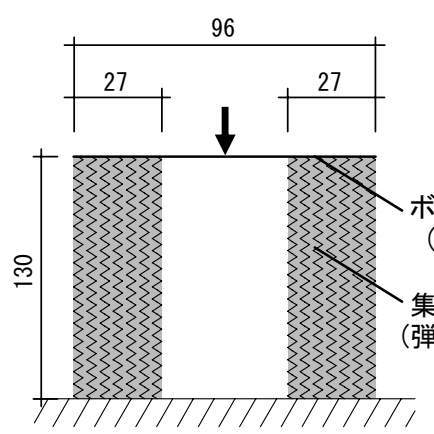

（a）シアリング接合の場合
(梁)

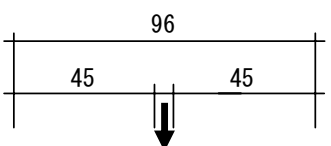

弾性床)

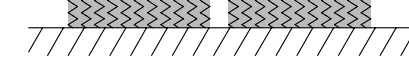

(b) ボルト接合の場合
図 10 ボルトとスギ集成材のモデル化（単位: mm）

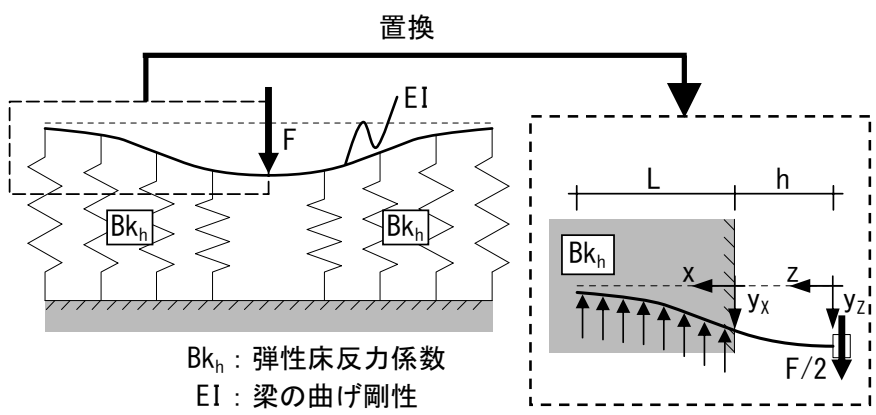

図 11 弾性床上の梁 


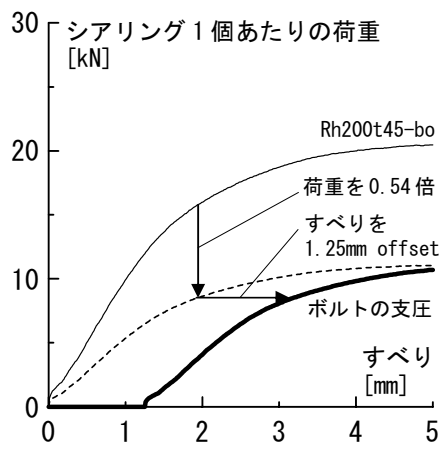

（a）ボルトの支圧部の荷重一すべり関係

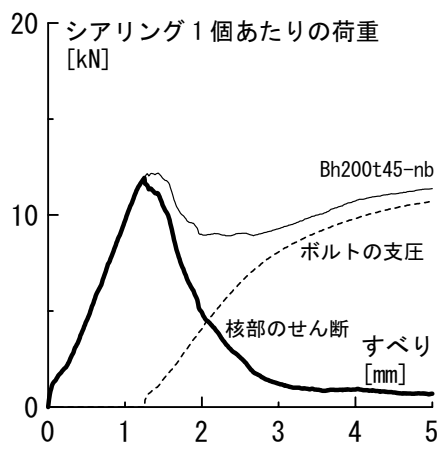

（b）核部のせん断の荷重一すべり関係
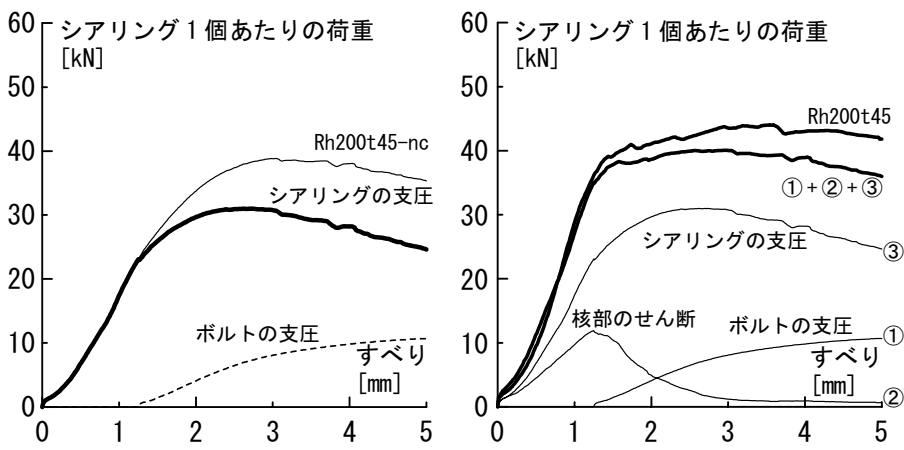

（c）シアリングの支圧部の荷重一すべり関係

図 12 シアリング接合における各荷重一すべり関係

\section{2 (2)核部の荷重一すべり関係の抽出}

(2)リングざぐり中央部の核部のせん断は, シアリングの支圧部の ない Bh100t45-nb 試験体から 4.1 節により求めたボルトの支圧分を 引くことで求めた。抽出されたリングざぐり中央部の核部の荷重一 す心゙り関係を図 12(b)に示す。核部のみの荷重一す心゙り関係からは, 荷重 $10 \mathrm{kN}$ 程度で核部がせん断ずれを起して耐力が低下し, その後 は核部のせん断面では力をほとんど伝達しない。

\section{3 ３シアリング支圧部の荷重一すべり関係の抽出}

(3)シアリングのスギ集成材に対する支圧は，核部のない Rh200t45-nc 試験体の荷重一すべり関係から 4.1 節により求めたボル トの支圧分を引くことで求めた。抽出された外側支圧部のみの荷重 一すべり関係を図 12(c)に示す。支圧部のみの荷重一す心゙り関係をみ ると, 荷重 $20 \mathrm{kN}$ 程度ですべり剛性が低下寸るが, シアリングのス ギ集成材支圧部分に対するめり込みによって耐力が $30 \mathrm{kN}$ 程度まで 増加し, その後はスギ集成材の材軸方向の亀裂と共に緩やかに耐力 が低下している。

\section{4 各部位で負担するカの割合}

図 12(d)に 4.1 節〜 4.3 節で求めた(1)ボルトのスギ集成材ボルト孔 に対する支圧，(2)リングざぐり中央部の核のせん断，(3)シアリング のスギ集成材に対する支圧，およびそれらの合計，Rh200t45 試験体 の荷重一すべり関係を示す。(1) + (2) + (3)で得られた曲線は, Rh200t45 試験体の荷重一寸べり関係に概ね一致している。このこと から, シアリング接合の力の伝達は, ボルトのスギ集成材ボルト孔 に対する支圧, リングざぐり中央部の核のせん断, シアリングのス ギ集成材に対する支圧であると考えることができる。

シアリング接合が負担する荷重を $100 \%$ として，各部位が負担し た力の割合, ならびに参考としてそのときの Rh200t45 試験体の荷重 一寸べり関係を破線で図 13 に示寸。荷重一寸べり関係における直線 域では，核部のせん断力とシアリングのスギ集成材に対する支圧に よって力を伝達している。その割合は, 核部のせん断力が $40 \%$ 程度 で，シアリングの外側の支圧で $60 \%$ 程度を負担している。すべり剛 性低下後は, 核部がせん断ずれを起し, 力をほとんど伝達しないた め, シアリングのスギ集成材に対する支圧とボルトのスギ集成材ボ ルト孔に対する支圧で力を伝達している。最大耐力に至るときは核 部で約 5\%, リング外側の支圧部で約 $75 \%$, ボルトで約 $20 \%$ の力を 負担している。

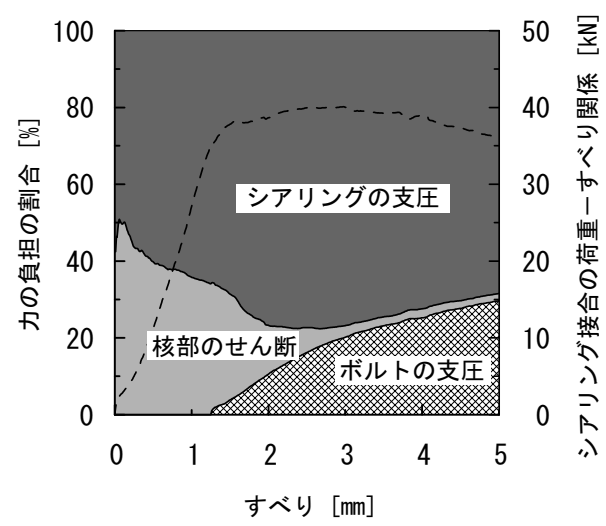

図 13 シアリング接合における力の負担の割合

\section{5. 結}

シアリング接合部の要素実験を行い，シアリング接合の初期す心゙ り剛性・耐力・破壊性状・力の伝達機構に関寸る基礎的なデータを 得た。以下に得られた知見をまとめる。

・シアリング接合をシアリング同士で押し合うように用いること を想定している場合，せん断実験はシアリング同士で押し合う形 式で行う必要がある。

・スギ集成材の材厚の影響は初期すべり剛性に関しては小さい。ま た，厚い方が勒性は高くなるが，最大耐力に関しては $45 \mathrm{~mm}$ (リン グ高さの 2.5 倍)以上の材厚を確保すれば影響はほとんどない。

・支圧部間の長さの影響は初期のすべり剛性に関しては小さい。

・シアリング接合の力の伝達が(1)ボルトのスギ集成材ボルト孔に 対する支圧，(2)リングざぐり中央の核部のせん断，(3)シアリング 外側のスギ集成材に対する支圧の 3 つにより行われると仮定し, それらの力の負担割合について把握した。

以上により，序で示したハイブリッド部材に用いたシアリング接 合部のせん断性能に関して把握することができた。本論文で示した シアリング接合における各要素の力の分担，すべりの挙動などのデ ータが，シアリング接合を用いた部材の設計に際し基礎的資料とな ると考える。しかしながら, 樹種, リングの形状, リングとざぐり のクリアランスなどのパラメータに対する検討は行っておらず，一 般性を持たせるためには，今後これらのパラメータのせん断性能に 対する把握を目的としたさらなる研究を行ってゆく必要がある。 


\section{謝辞}

東京工業大学建築物理研究センター教授・工学博士 和田章先生に は，本研究を進めるにあたり貴重な御助言を戴きました。播設計室 播繁氏，樋口聡氏には，ハイブリッド部材の開発に関する貴重なご 助言，ご意見を戴きました。ここに感謝の意を表します。新日鉄エ ンジニアリング株式会社・博士(工学) 佐伯英一郎氏には, 本研究の 意義を御理解戴くと共に，多大なるご協力を戴きました，ここに感 謝の意を表します。

\section{参考文献}

1) 堀井健史, 坂田弘安，竹内徹，鈴木達人，中村博志：シアリング接合を用 いた杉集成材と鋼板によるハイブリッド部材の力学的挙動に関する実験研 究, 日本建築学会構造系論文集, 第 584 号, pp. 125-132, 2004.10

2) 福田重義: 輪形ヂベルに依る木材接合部の耐力実験, 建築學會大會論文 集, pp.230-239, 1939.4

3) 長沼重: 木材の輪形ヂベル接合部に関する理論的研究, 建築學會大會論 文集, pp.240-245, 1939.4
4) 原田有, 倉林元一: 輪形ヂベルを用ひたる木材接手に関する実験報告(其 の 1), 建築學會大會論文集, pp.246-255, 1939.4

5)神谷文夫, 杉本健一, 鴐海四郎: $102 \mathrm{~mm}$ シアプレート $102 \mathrm{~mm}$ スプリット リングの接合強度, 日本建築学会大会学術講演梗概集, C, pp.119-120, 1990.10

6) 大橋好光, 飯村豊: $102 \mathrm{~mm}$ シアプレートのせん断耐力実験 一繊維平行方 向について-, 日本建築学会大会学術講演梗概集, C, pp.43-44, 1992.8

7) 洞陽子, 今井克彦, 古川忠稔, 藤田宣紀, 稲田雅宣, 㴰野敦夫, 渡辺仁美: 重衫梁接合部のせん断耐力に関する研究 (その 2) 接合部のせん断耐力, 日 本建築学会大会学術講演梗概集, C-1, pp.515-516, 2003.9

8) 神野圭祐, 洞陽子, 藤田宣紀, 今井克彦: 重䃿梁接合部のせん断耐力に 関する研究及び実大曲げ試験 (その1) 接合部の押し抜き試験, 日本建築学 会大会学術講演梗概集, C-1, pp.243-244, 2005.9

9) John A. Scholten: Timber-Connector Joints; Their Strength and Design, U. S. Department of Agriculture, Technical Bulletin No.865, 1944.3

10) Marie-Anne Erki, Mark W. Huggins: Load Capacity of Row of Shear Plate Connectors, Journal of Structural Engineering, ASCE, Vol.109, No.12, pp.2786-2801. 1983.12

11）横山幸満: 〈い構造物の計算法と計算例，山海堂, 1978.6

(2007年 7 月 10 日原稿受理，2008年 2 月 6 日採用決定） 